\title{
Santa Marta, guardiana de hogares ajenos ${ }^{1}$ Saint Martha, patron saint of other people's homes
}

\author{
Patricia GRAU-DIECKMANN \\ pgraud@gmail.com
}

Recibido: $16 / 05 / 2017$

Aceptado: 27/06/2017

Resumen: La historia de Santa Marta es paradojal y conmovedora. Representada en el arte con una escoba y un cucharón, que la marcan como encargada de las tareas domésticas, vive a la sombra de sus hermanos María de Betania - la Magdalena- y el resucitado Lázaro. Es la silenciosa mujer que toca el ruedo de Jesús con la esperanza de curar su vergonzante hemorragia menstrual; es la que debe limpiar y cocinar mientras su espiritual hermana, que "elige la mejor parte", permanece absorta (y ociosa) ante las palabras de Jesús. Luego de una dolorosa agonía, el dramático protagonismo de Marta en su propia muerte era un hecho innegable, pero este le es arrebatado teatralmente cuando inesperadamente un coro de ángeles transporta gloriosamente a los cielos el alma de su hermana. Santa Marta muere días después, a la intemperie, humildemente acostada en el piso, sin ángeles y sin música. Murió como vivió, sin estridencias. Mujer sin hombre, familia, ni hogar propios, la virgen Marta es, paradójicamente, venerada como patrona de las amas de casa.

Palabras clave: Santa Marta, Tarasca, dragona, María Magdalena, amas de casa.

Abstract: The story of Saint Martha is both paradoxical and touching. Represented in art with a broom and a ladle appointing her as housewife, she lives at the shadow of her siblings Maria of Bethany-Mary Magdalene - and the resurrected Lazarus. She is the silent woman who touches the hem of Jesus in the hope of curing her shameful menstrual bleeding. She is the one who must clean and cook while her spiritual sister - whom in the words of Jesus, "chooses the best part"remains absorbed (and idle). After a painful agony, the main dramatic role of Martha in her own death was an undeniable fact, but her final act is stolen theatrically when an unexpected choir of angels conveys gloriously to heaven the soul of her sister. Saint Martha dies some days later, outdoors, humbly lying on the floor, with no angels and no music. She died the way she lived, with no stridency. Woman with no man, family, or home of her own, Martha the virgin is, paradoxically, venerated as the patroness of housewives.

Key words: Saint Martha, Tarasque, dragoness, Mary Magdalene, housewives.

Sumario: 1. Antecedentes familiares. 2. Vida activa vs. vida contemplativa. 3. La hemorroísa. 4. La leyenda provenzal. 5. Muerte de Santa Marta. 6. Conclusión. Fuentes y Bibliografía

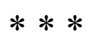

\footnotetext{
${ }^{1}$ El presente artículo es una versión revisada y corregida del original publicado en Arqueología, Historia y viajes sobre el mundo Medieval, Número 36, septiembre 2010, Barcelona, España, ISSN: 1698-0387, pp. 55-62. Se publica con la amable autorización de Ariel Vila Redondo, ex director de la revista.
} 


\section{Antecedentes familiares}

Según el Evangelio Armenio de la Infancia (siglo IV) ${ }^{2}$, la relación de Jesús con Lázaro, María y Marta comienza cuando la Sagrada Familia huye a Egipto y el padre de los tres niños, el príncipe hebreo Eleazar, les brinda asilo. Esta temprana amistad infantil explica la familiaridad en el trato y la deferencia de Jesús hacia los tres hermanos cuando todos vuelven a reunirse, ya adultos, en Betania. Hay dos localidades en Tierra Santa llamadas Betania. Una es donde Juan bautizaba, al otro lado del río Jordán. La otra es un pueblo enclavado en la pendiente oriental del Monte de los Olivos, a menos de $3 \mathrm{Km}$. de Jerusalén. En la actualidad, la aldea se llama El Azariyeh, transcripción árabe del nombre bizantino Lazarion, ${ }^{3}$ porque allí se encuentra la tumba de Lázaro, hoy en día ubicada debajo de una mezquita. ${ }^{4}$

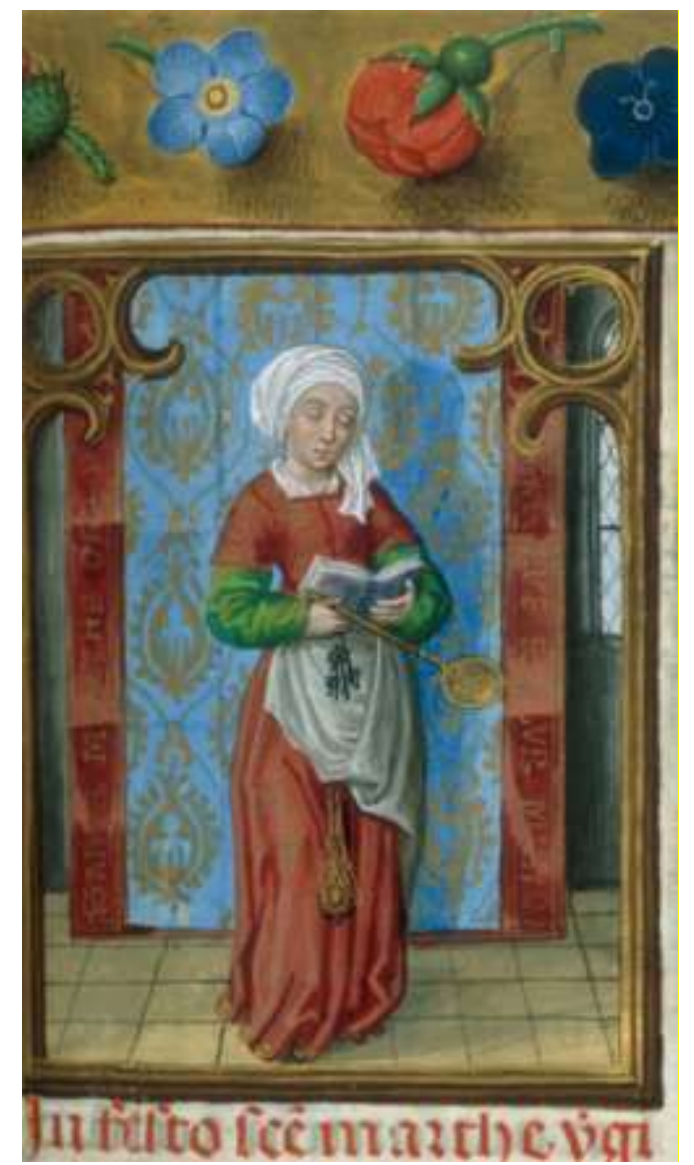

Fig. 1. Santa Marta, Breviario de Isabel la Católica, ca. 1497, 230 x 160 mm., Add MS 18851. Tomado de https://es.wikipedia.org/wiki/Archivo:Saint_martha.jpg

${ }^{2}$ Evangelios Apócrifos, Ed. Hyspamérica, Ediciones Argentinas S.A., Buenos Aires, 1985, Tomo 1, Evangelio Armenio de la Infancia, Cap. XV, 24, pp. 206/207.

${ }^{3}$ GERARD, André-Marie, Diccionario de la Biblia; p.188.

${ }^{4}$ GONEN, Rivka, Biblical Holy Places, p. 50/1. 
Jacobus de Voragine en su Leyenda Dorada (1263) brinda datos diferentes y señala que su padre era de sangre real, se llamaba Syrus, y era gobernador de Siria y de muchas otras tierras. Marta había heredado de su madre Aucharia las ciudades de Magdala, las dos Betanias, y parte de Jerusalén. ${ }^{5}$ Sin embargo, en su relato específico sobre María Magdalena, Voragine se contradice a sí mismo y narra que María se quedó con Magdala (de ahí su nombre, Magdalena), Lázaro con la parte de Jerusalén y Marta con Betania, sin especificar cuál de ambas ciudades. ${ }^{6}$

\section{Vida activa vs. vida contemplativa}

Lucas (10:38-42) ${ }^{7}$ relata que Jesús y sus acompañantes son recibidos en casa de los tres hermanos y Marta, diligente, se esmera en atender a sus huéspedes mientras María, sentada a los pies de Jesús, lo escucha embelesada. La hospitalidad era muy apreciada en Medio Oriente, lo que explica la molestia de Marta por la actitud de su hermana. Se queja directamente al visitante y le pide que intervenga para que esta la ayude en las tareas domésticas. Jesús le contesta: "Marta, Marta, tú te preocupas y te apuras por muchas cosas y solo es necesaria una. María ha escogido la parte mejor, que no se le quitará". Su tono no es de reproche, sino que, con cariño, aconseja a Marta no dejarse ganar por la autocompasión. Este episodio será la base que marcará la dicotomía que se establecerá entre ambas hermanas. Marta representará la vida activa y María la contemplativa.

Juan (11:1-53) narra que Lázaro enferma en Betania y sus hermanas mandan decir a Jesús: "El que amas está enfermo". Jesús contesta: "Esta enfermedad no es de muerte, sino para gloria de Dios, a fin de que por ella sea glorificado el Hijo de Dios". Tras demorarse dos días, anuncia a sus discípulos que regresará a Judea pues "Lázaro, nuestro amigo, duerme, pero voy a despertarlo", refiriéndose no al sueño, sino a la muerte de Lázaro. Este ya llevaba cuatro días muerto y la casa se encontraba llena de gente que había ido a consolar a las hermanas. Al enterarse de que Jesús estaba llegando, Marta abandonó a sus huéspedes — como si ya hubiera aprendido su lección - y va a su encuentro, mientras María queda en el interior de la casa, llorando. Dice Marta:

"Señor, si hubieras estado aquí, no habría muerto mi hermano. Pero ya sé que Dios te concederá lo que le pidas." Jesús le dijo: "Tu hermano resucitará". Marta

\footnotetext{
${ }^{5}$ Voragine, Jacobus de, The Golden Legend, Vol I, pp 374 y ss. y Vol. II, p. 24 y ss.

${ }^{6}$ VORAGINE, op. cit., p. 375.

${ }^{7}$ Biblia de Jerusalén, Bilbao, Desclée de Brouwer, 1998. Todas las citas bíblicas están tomadas de esta fuente.
} 
le respondió: "Sé que resucitará cuando la resurrección, el último día". Jesús le dijo: "Yo soy la resurrección y la vida. El que cree en mí, aunque muera, vivirá. Y todo el que vive y cree en mí no morirá para siempre. ¿Crees esto?" Dícele: "Sí, Señor, yo creo que tú eres el Cristo, el Hijo de Dios, que ha venido al mundo".

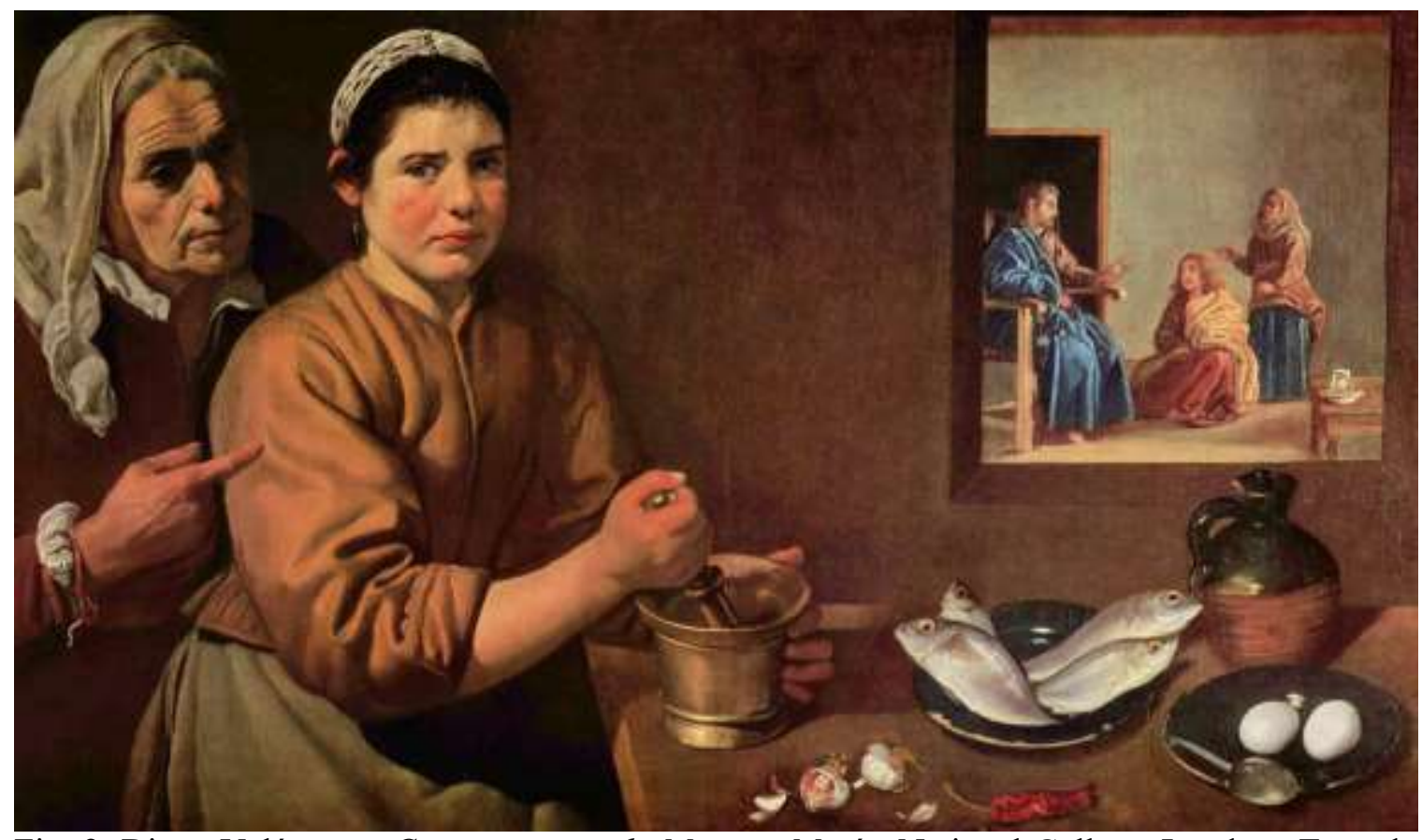

Fig. 2. Diego Velázquez, Cristo en casa de Marta y María. National Gallery, Londres. Tomado de https://arguments.es/arte/portfolio/jesus-en-casa-de-marta-y-maria-diego-velazquez-1618/

Marta pide humildemente a Jesús el milagro de una resucitación. Y declara con sencillez que cree que Jesús es efectivamente el Cristo, el Mesías esperado, el Hijo de Dios.

Ante la tumba de Lázaro, Jesús no puede evitar derramar una lágrima. Según la leyenda, esta Lacrima Domini (Lágrima del Señor o Sainte Larme) fue recogida por María y oportunamente llevada a Provenza, donde se conservó en un recipiente de cristal, cuya pía exhibición producía cuatro mil libras anuales a los monjes benedictinos. ${ }^{8}$ Invocada para curar los males oculares, la Santa Lágrima era en realidad un pedazo de cristal de roca cuyo centro semejaba una temblorosa gota transparente.

Jesús regresa a la casa de los hermanos en Betania (Juan 12:1-9), y mientras María unge sus pies con un costoso óleo y los seca con sus cabellos, "Marta servía", dice escuetamente el evangelio sobre esta silenciosa y sacrificada mujer. Lázaro había causado un revuelo con su regreso del mundo de los muertos, María produce un escándalo al derrochar la oleosa fragancia. Pero la discreta Marta no está en el centro de atención. Ella simplemente sirve a Jesús.

\footnotetext{
${ }^{8}$ RÉAU, Louis, Iconografía del Arte Cristiano, Tomo 1, vol. 2:, p. 21.
} 


\section{La hemorroísa}

En una ocasión Jesús se encontraba rodeado por una multitud y una mujer que padecía de flujo de sangre desde hacía doce años tocó la orla de su manto, e instantáneamente se sintió curada. ${ }^{9}$

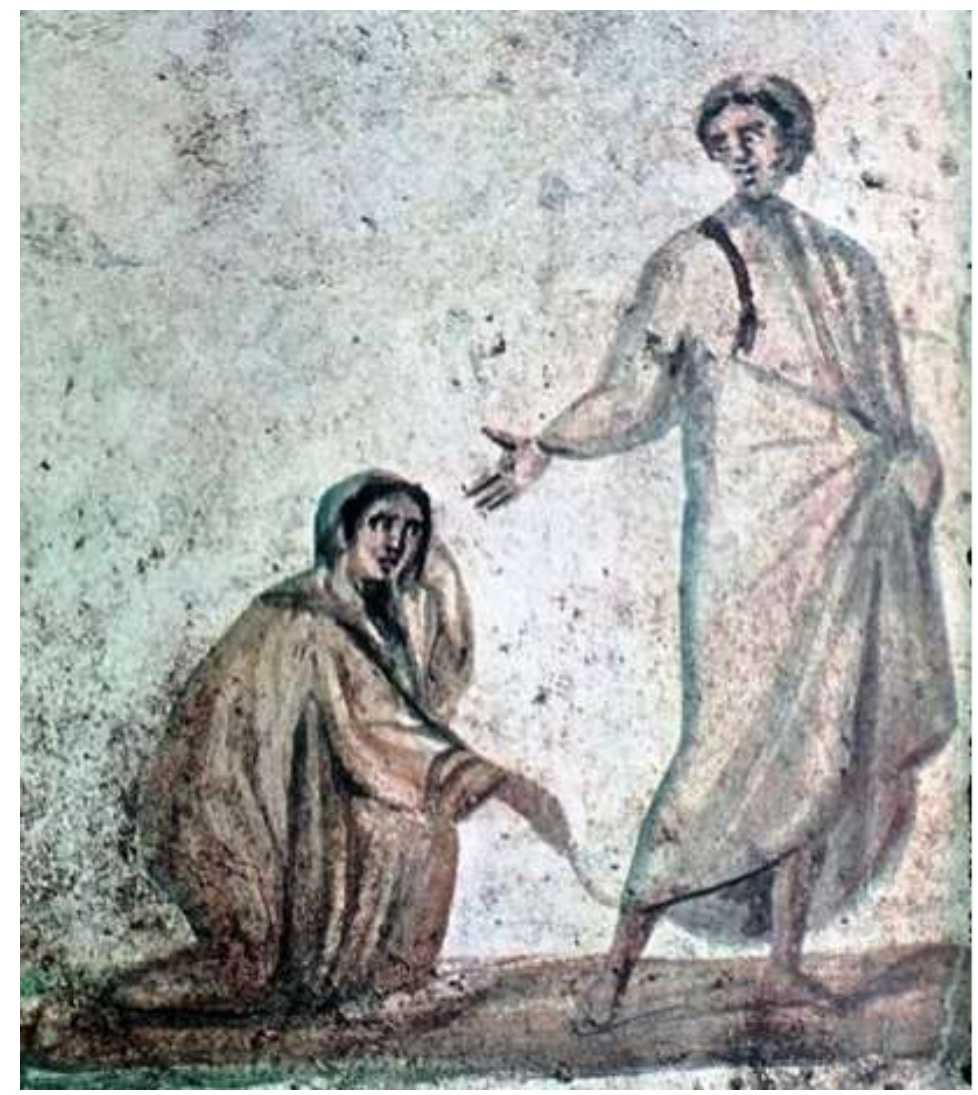

Fig. 3. Hemorroísa. San Pedro y Marcelino, luneto del cuarto 65, fines siglo III y principios del IV. Tomado de https://es.pinterest.com/pin/569142471639943730/

San Ambrosio (siglo IV) es el primero que identifica a la hemorroísa con Marta de Betania, ${ }^{10}$ identificación que luego será aceptada prácticamente sin discusión. Eusebio de Cesarea (también del siglo IV) relata en la Historia Eclesiástica que la mujer curada mandó erigir en su jardín una estatua de Cristo vestido con el mismo ropaje con que efectuara el milagro. La hierba alrededor de la estatua adquiría poderes curativos cuando crecía y tocaba el ruedo de la túnica.

(...) Efectivamente, sobre la piedra alta, delante de las puertas de su casa, se alza una estatua de mujer, en bronce, con una rodilla doblada y con las manos tendidas hacia delante como una suplicante;

\footnotetext{
${ }^{9}$ Mateo 9:20-22; Marcos 5:25-35 y Lucas 8:43-48.

${ }^{10}$ RÉAU, Louis, Iconografía del Arte Cristiano, Tomo 1, vol. 2, p. 344.
} 
y enfrente de esta, otra del mismo material, efigie de un hombre en pie, revestido pulcramente con un manto y tendiendo su mano hacia la mujer. A sus pies, sobre la misma estela, brota una extraña especie de planta, que sube hasta la orla del manto de bronce y resulta un antídoto contra toda clase de enfermedades. Esta estatua dicen que reproducía la imagen de Jesús. Se conservaba hasta nuestros días, como lo hemos comprobado de vista nosotros mismos, de paso en aquella ciudad. ${ }^{11}$

San Jerónimo (siglo V) en la Historia Tripartita cuenta que Juliano el Apóstata, el emperador romano que impuso la religión pagana entre 331 y 363, retiró la estatua y puso en su lugar una suya, pero que esta fue poco después destruida por un rayo. ${ }^{12}$

Jacobus de Voragine en su Leyenda Dorada ${ }^{13}$ sostiene que pese a ser la patrona de los quehaceres domésticos y de las amas de casa, no hay ningún indicio de que Marta se hubiera casado o tenido intimidad con hombre alguno. ${ }^{14} \mathrm{Su}$ estado civil de persistente soltería es coherente con la tradición que la relaciona con la hemorroísa, ya que, según las costumbres judías, su situación de permanente menstruación la colocaba en un estado de constante impureza. Además, su imposibilidad de quedar embarazada constituía otro impedimento para contraer matrimonio. Tras su curación, decide mantenerse virgen, pero lo hace por propia decisión.

\section{La leyenda provenzal}

La imagen más difundida de Santa Marta es junto a un dragón, iconografía que tiene su origen en una leyenda tardía fraguada por los religiosos de la Provenza necesitados de reliquias de peso para atraer peregrinos que proporcionaran ingentes ganancias. En el siglo XIII, los monjes del sur de Francia, con gran visión, inventaron una historia que involucra a varios de los personajes santos más cercanos a Jesús. Cuenta la leyenda que tras la muerte del Maestro un grupo formado por Marta, Lázaro, María Magdalena, el obispo Maximino (uno de los 72 discípulos), Cedonio (el ciego de nacimiento curado por Jesús), María la de Cleofás y María Salomé, ${ }^{15}$ son arrojados al mar en una balsa sin remos, velas o

\footnotetext{
${ }^{11}$ Eusebio de CESAREA, Historia Eclesiástica, Libro VII, 18.

${ }^{12}$ Voragine, Jacobus de, The Golden Legend, Vol. II, p. 24.

131263.

${ }^{14}$ VorAGINE, op. cit. p. 23

${ }^{15}$ Algunas versiones indican que ambas eran hermanas de la Virgen María, y que María la de Cleofás era madre de Santiago el Menor y María Salomé, esposa del Zebedeo, la de Santiago el Mayor y Juan Evangelista.
} 
timón. Milagrosamente recalan en el puerto de Massilia, hoy Marsella, en la Provenza. Se establecieron en los alrededores de Aix, y Marta, con su elocuencia y gentileza, convirtió a muchos lugareños al cristianismo.

A orillas del Ródano vivía la Tarasca, un monstruo mitad animal terrestre, mitad pez. Se la describe "grande como un buey, más largo que un caballo, con dientes afilados como puñales y una caparazón impenetrable que cubría todo su cuerpo". ${ }^{16}$ Otros dicen que era más grande que doce elefantes, sus dientes eran como espadas de marfil y su piel como hierro. Tenía seis poderosas piernas, cada una equipada con la garra asesina de un oso gigantesco. Su cabeza era la de un león con gran melena dorada; una caparazón masiva cubría su espalda, como la cobertura de una tortuga gigante pero revestida con pinchos poderosos. Su cola serpentina terminaba en una púa afilada como punta de lanza. Y su aliento eran lenguas de fuego. Acechaba en el río y mataba a todos cuantos intentaban navegarlo. Entraba a la aldea de Nerluc y se llevaba a sus habitantes. La leyenda se dramatizó aún más, y con el tiempo asumió la forma de uno de los mitos clásicos presentes en muchas historias, ya que se decía que Tarasca debía consumir semanalmente una virgen. El monstruo era de sexo femenino y provenía de Galacia, en Asia Menor central. ${ }^{17}$ Era hija de Leviatán — bestia marina que en las Escrituras Hebreas representa las fuerzas del caos opuestas a Dios- ${ }^{18}$ y de Onaco, animal criado en las regiones de la Galacia que arrojaba su boñiga cual dardos a sus perseguidores, quemándolos "como con fuego". 19

Las diferentes historias hebreas sobre Leviatán, relatan que

los colmillos del monstruo Leviatán difundían el terror, de su boca salían fuego y llamas, de las ventanas de su nariz, humo, de sus ojos un feroz rayo de luz; su corazón carecía de compasión. Vagaba a voluntad por la superficie del mar, dejando una estela resplandeciente; o por su abismo inferior, haciendo que hirviese como una olla. Ninguna arma del arsenal de la humanidad podía abollar sus escamas. Los habitantes del Cielo mismo lo temían. Pero Dios pescó a Leviatán con un anzuelo, lo sacó del mar, le ató la lengua con una cuerda, le atravesó las ventanas de la nariz con una caña y le taladró las mandíbulas con una espina ${ }^{20}$. (...) Leviatán solo le teme a una

\footnotetext{
${ }^{16}$ VorAgine, Jacobus de, The Golden Legend, Vol. II, p. 23. Todas las traducciones del inglés son responsabilidad de la autora.

${ }^{17}$ Sugestivamente, la Galacia había sido vasalla de Siria, la tierra de Marta, en el año 275 a. C. El padre de Marta había sido gobernador de Siria en tiempos romanos.

${ }^{18}$ The Oxford Dictionary of World Religions, p. 575.

${ }^{19}$ Voragine, op. cit., Vol. II, p. 24.

${ }^{20}$ GRAVES, Robert, PATAI, Raphael, Los Mitos Hebreos, Editorial Losada, Buenos Aires, 1969, pp. $49-50$.
} 
criatura: un pececito llamado Chalkis, creado por Dios con el único propósito de refrenarlo (...) Exhala un hedor terrible. Si no fuera porque de vez en cuando el monstruo se purifica olfateando las fragantes flores de Edén, todas las criaturas de Dios se asfixiarían seguramente. ${ }^{21}$

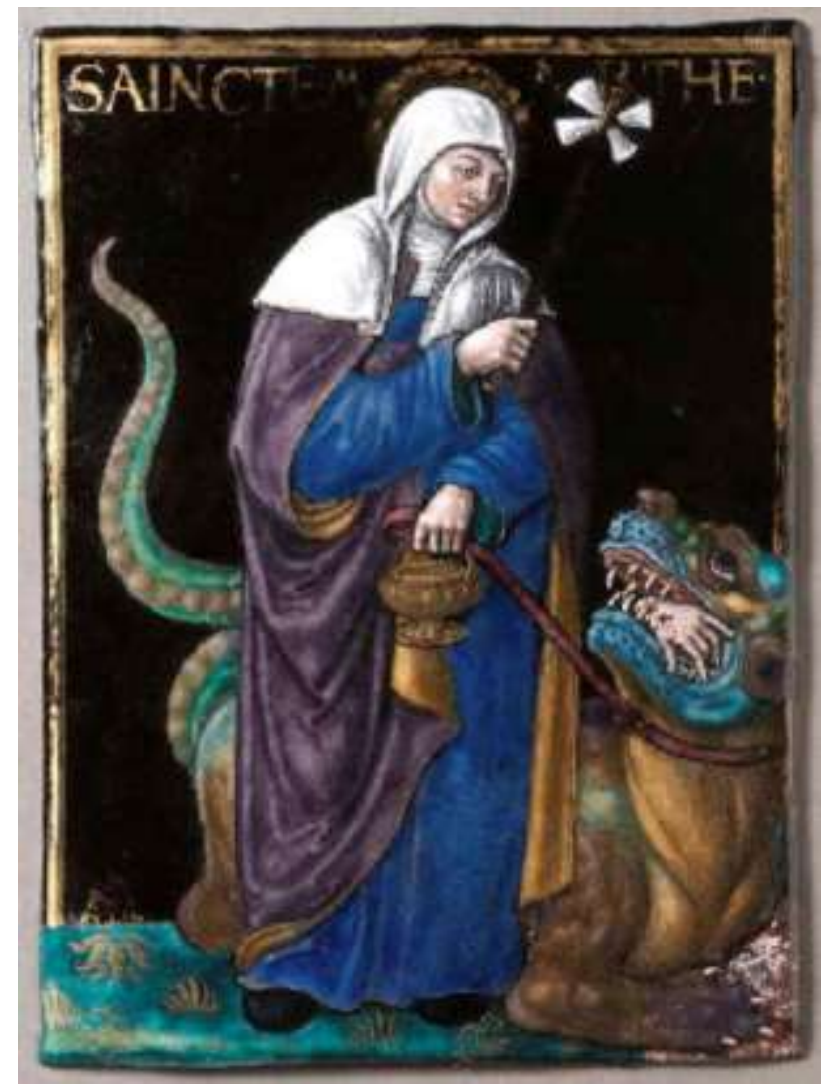

Fig. 4. Santa Marta, placa del Frente de Altar de Lyon, atribuido a Jehan Limosin, principios del siglo XVII, Museo de Bellas Artes de Lyon. Tomado de http://fmoreau.recit.free.fr/index.php?ref=MFU8196

El chalkis es un pez gregario. A veces se dice que es una sardina y otras que es un arenque. ${ }^{22}$

Algunas tradiciones rabínicas consideran a Leviatán un dragón andrógino que, como forma femenina (Lilith) sedujo a Adán, y como monstruo masculino, tomó el nombre de Samael y atrajo a Eva, con quien concibió a Caín. ${ }^{23}$ Su hija Tarasca era imposible de vencer. En cierta ocasión encontraron el pellejo del monstruo y creyeron que había muerto pero, cada siete años, como los reptiles, mudaba de piel. Los habitantes de Nerluc pidieron ayuda a Marta, que convertía a las gentes

${ }^{21}$ GRAVES, op. cit., pp. 50 y 51.

${ }^{22}$ Ambos peces son muy parecidos.

${ }^{23}$ KONING, Frederik, Diccionario de demonologia, p. 159. 
con el don de su palabra. Ella, con su vestido blanco y descalza, llevando un jarro de agua bendita, la encontró devorando un hombre. Improvisó una cruz con dos ramas calcinadas por el aliento de Tarasca y cantando alabanzas a Dios, la roció con agua bendita. La dragona se echó pasivamente a los pies de Marta, quien cortó su propio cabello con un diente del monstruo y tejió una soga para llevarla dócilmente a Nerluc. Los vecinos, envalentonados por la mansedumbre de Tarasca, la mataron con piedras y espadas, pese a los ruegos de Marta. Esta vez sus palabras elocuentes no causaron el efecto acostumbrado.

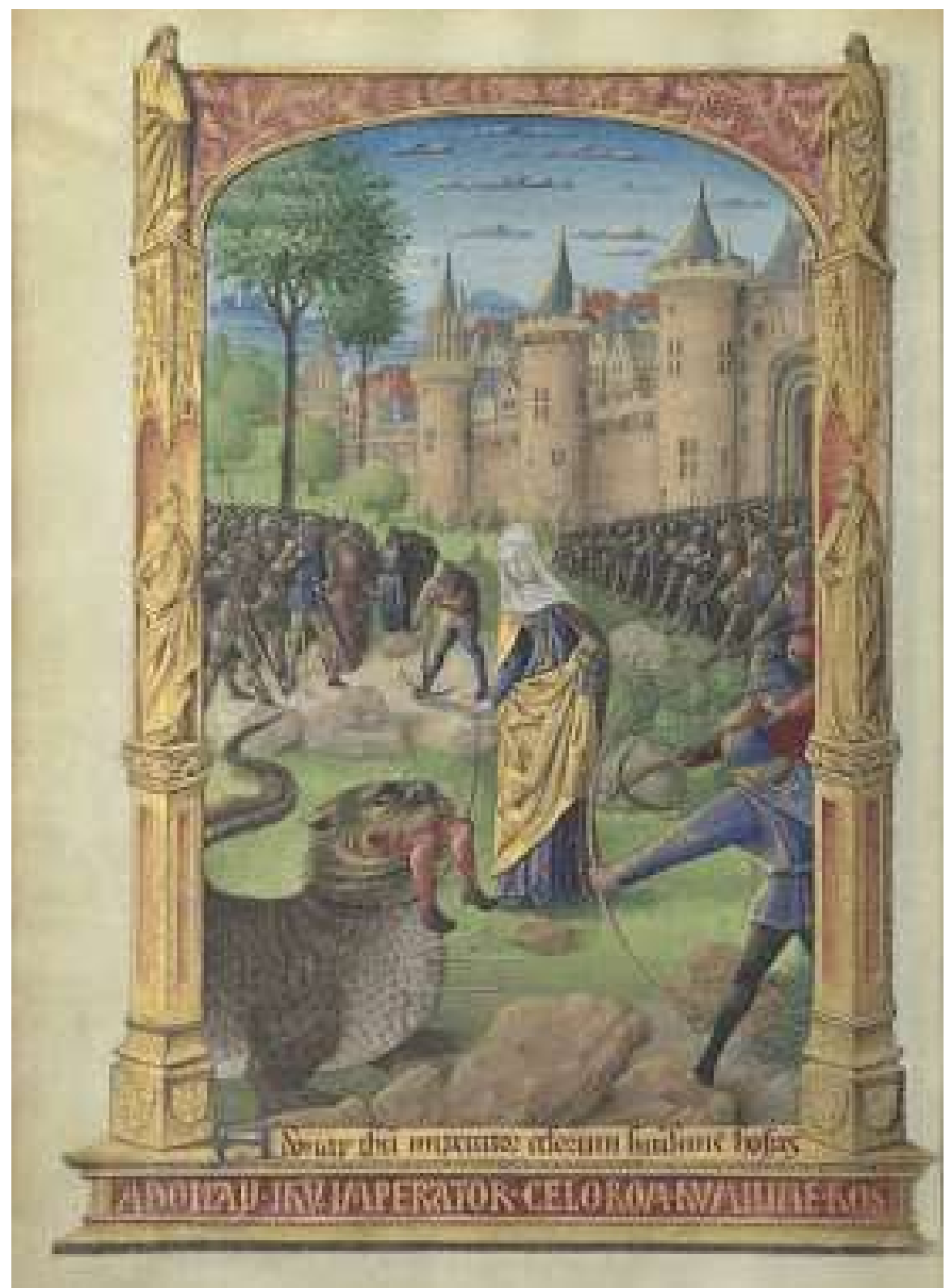

Fig. 5. Santa Marta y Tarasca, Horas de Louis de Laval, 1470/85, Bibliotèque Nationale de France, ms Latin 920, f. 317v. Tomado de http://www.newliturgicalmovement.org/2016/07/stmartha-kills-dragon.html\#.WQeh_yMrLbg 
La región pasó a llamarse Tarascón en recuerdo del episodio. A partir del siglo $\mathrm{XV}$, tanto en esa región de Francia como en algunas ciudades de España, una imagen de la Tarasca desfila en la procesión del Corpus junto a las imágenes santas. Voragine relata que Marta se dedicó luego a la plegaria y al ayuno, tras solicitar permiso al obispo Maximino y a su hermana María, lo que señala su reiterada posición secundaria y subordinada. Fundó una congregación lega que no comía carne, grasas, huevos, queso, y que no bebía vino. Las hermanas comían una sola vez al día y realizaban tres genuflexiones de día, y tres de noche. Realizó varios milagros, el más destacado la resucitación de un joven ahogado al intentar cruzar un río para oír más claramente la palabra de Marta. Esta se acostó en el piso con los brazos abiertos en cruz y rezó a Jesucristo, apelando a que una vez había resucitado a su hermano Lázaro. Lo llama "mi querido huésped", recordándole que había sido su anfitriona. ${ }^{24}$

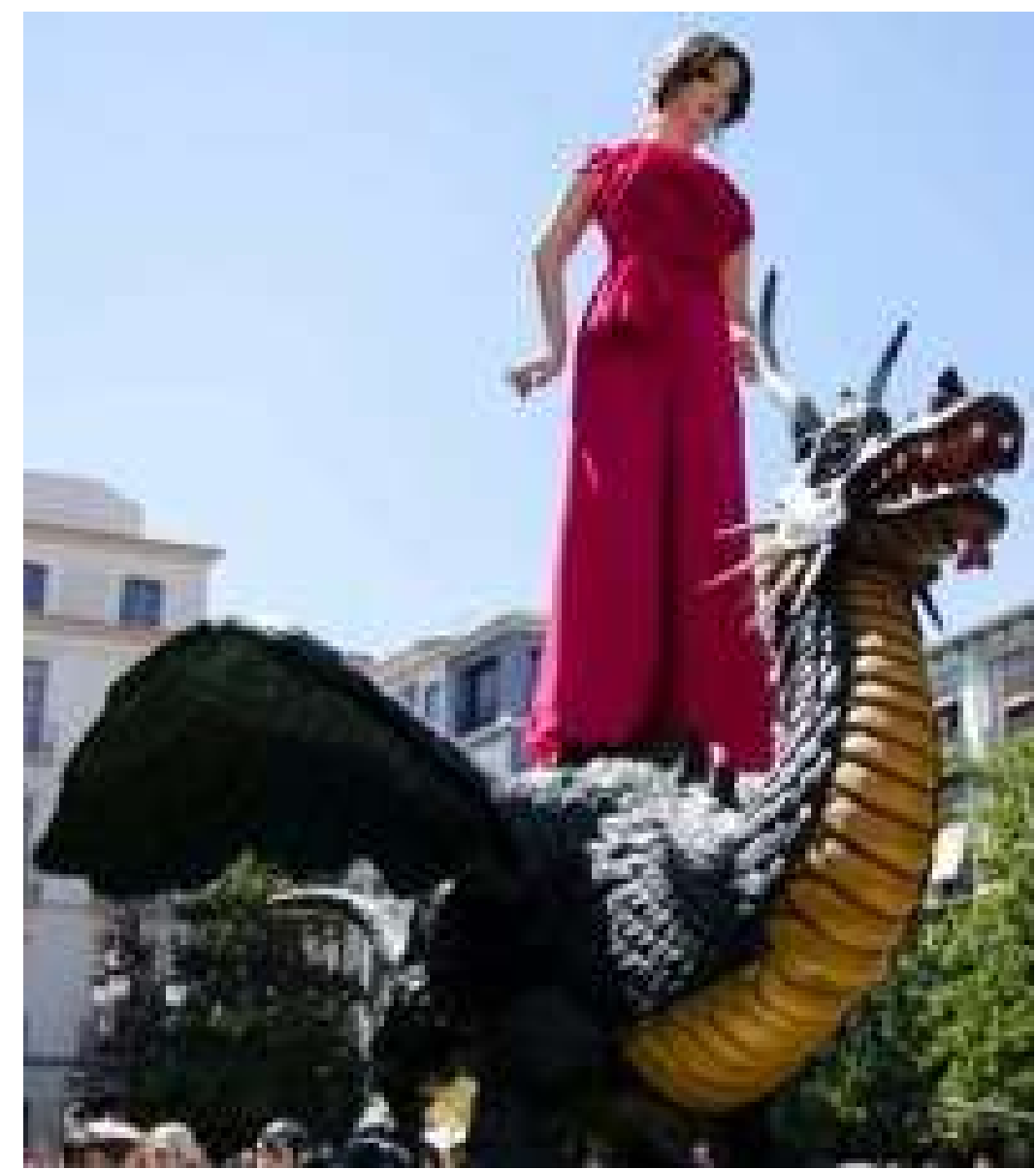

Fig. 6. Desfile de Tarasca en Corpus Christi en Granada, España.

Tomado de http://www.granadadigital.es/tag/tarasca/?print=print-search

${ }^{24}$ Voragine, Jacobus de, The Golden Legend, Vol. II, p. 25. 


\section{Muerte de Santa Marta}

Jesús le anuncia su muerte con un año de anticipación, penoso año durante el cual sufrió continuos ataques de fiebre, pero que le permitió prepararse espiritualmente para una muerte memorable que seguramente la compensaría de una opaca vida de postergaciones. Pero una semana antes de su partida, su hermana Magdalena muere y su alma es transportada al cielo por un coro de ángeles. La gloriosa muerte para la que se venía preparando le es arrebatada a Marta muy cerca del desenlace. Siempre segunda, la relegada y dulce Marta es testigo auditivo de un coro angelical que no cantará para ella.

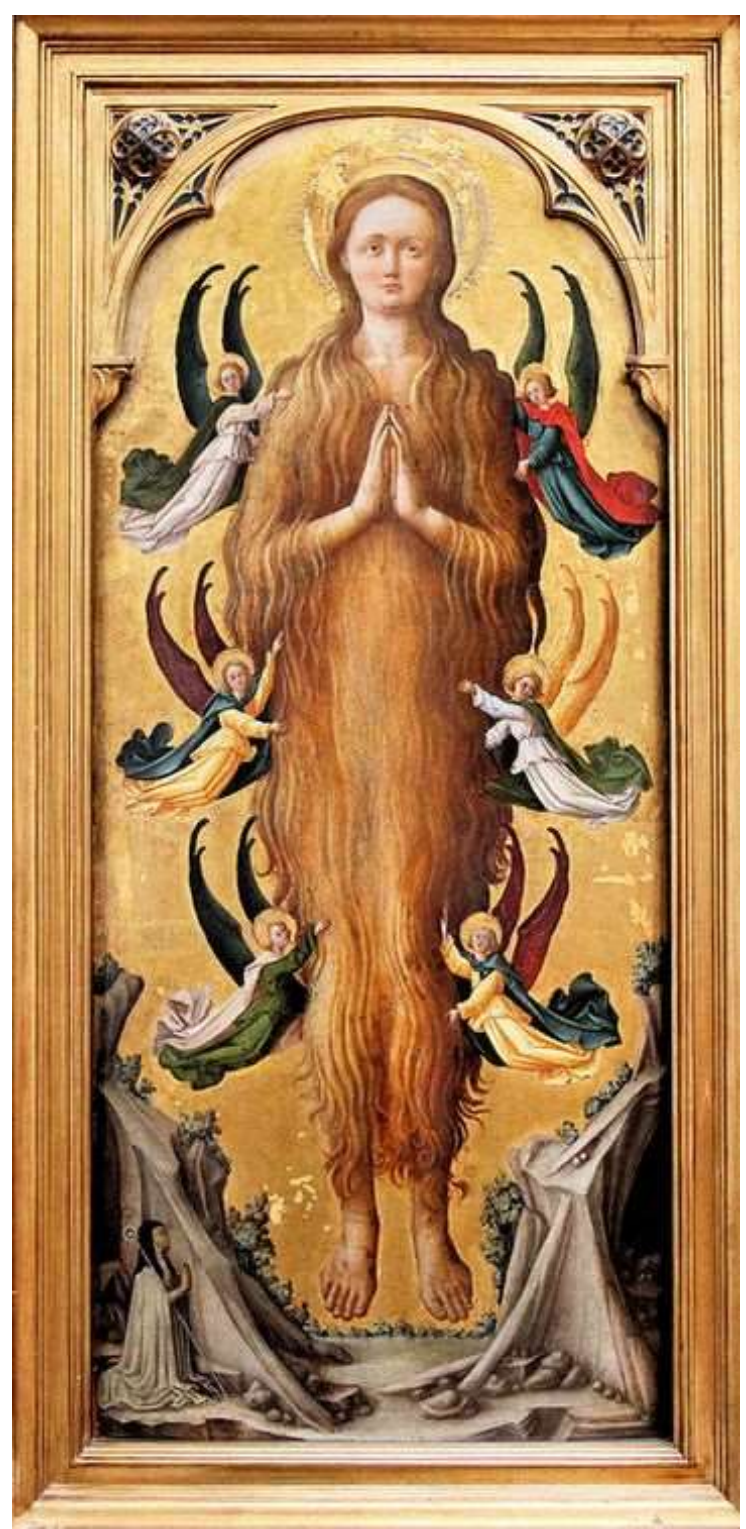

Fig. 7. Antonio Vivarini, La Ascensión de María Magdalena, 1476, Gemäldegalerie, Berlín. Tomado de https://es.wikipedia.org/wiki/Archivo:1476_Vivarini_Himmelfahrt_Maria_Magdalenas_anagoria.JPG 
La noche de su muerte, presintiendo el final, Marta pidió a sus compañeras que mantuvieran las lámparas encendidas para acompañarla hasta el momento de su partida. Estas se quedaron dormidas y un fuerte viento apagó las lámparas. Marta fue rodeada de espíritus malignos y comenzó a orar mientras clamaba "mis seductores que quieren devorarme", refiriéndose a los demonios. María Magdalena - siempre protagonista - se manifestó a la moribunda con una antorcha, y encendió todas las velas y lámparas. Luego Jesús apareció y le dijo "Ven, mi amada anfitriona, y donde yo esté, allí estarás tú también. Me diste la bienvenida a tu casa y ahora yo te daré la bienvenida al Paraíso, y por amor a ti, favoreceré a los que te invoquen". ${ }^{25}$ Marta pidió ser transportada al exterior y allí, en soledad, humildemente acostada sobre cenizas, expiró.

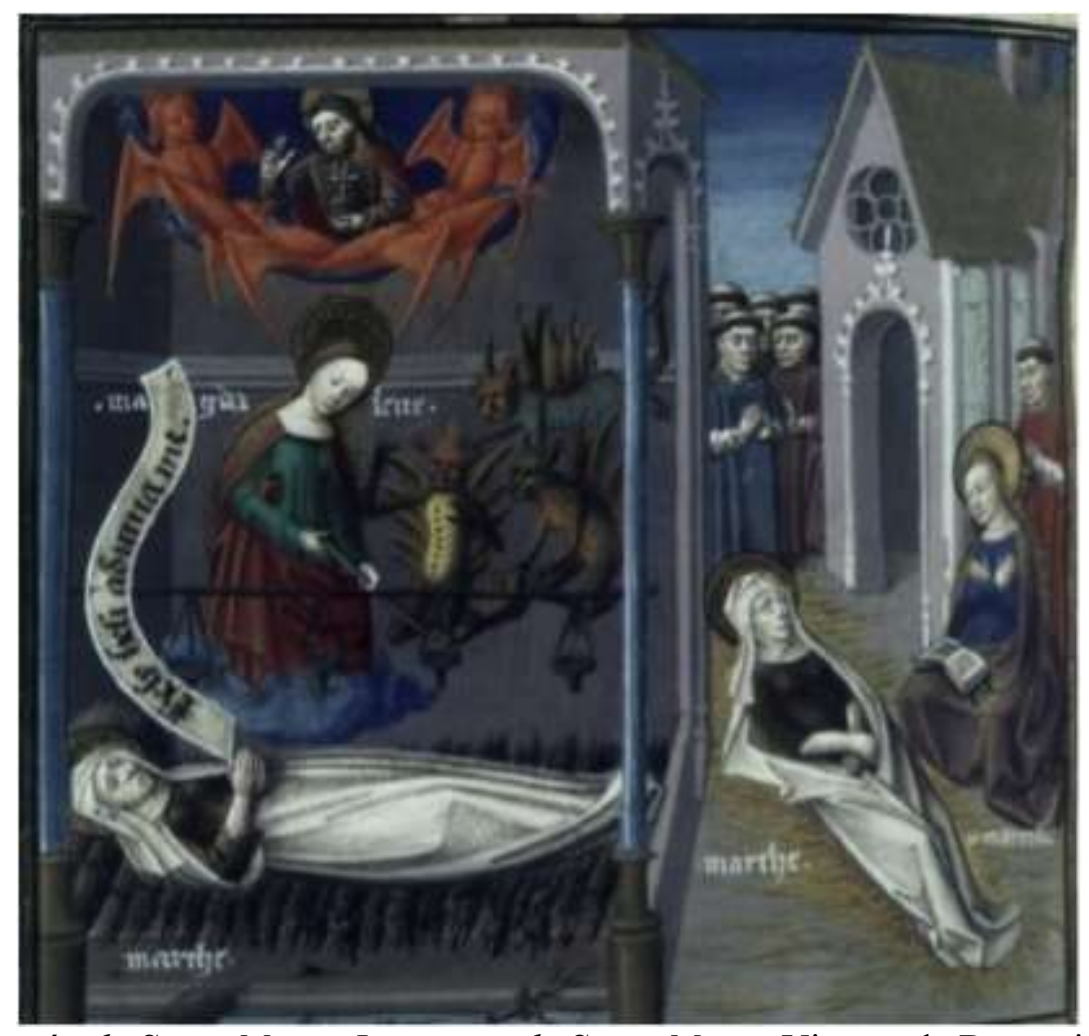

Fig. 8. La visión de Santa Marta. La muerte de Santa Marta, Vicente de Beauvais, Historical Speculum, S. XV. Tomado de http://har22201.blogspot.com.ar/2012/07/sainte-marthe.html

El relato sobre las lámparas presenta una interesante connotación. Es una recreación del episodio de Mateo 25:1-3 sobre las vírgenes prudentes y las vírgenes necias. Todas ellas forman parte del cortejo de una novia que espera al esposo para celebrar las nupcias. Este se retrasa y llega de noche. Las prudentes, alertas y precavidas, habían llenado sus lámparas de aceite para encenderlas oportunamente. Las vírgenes necias, holgazanas y descuidadas, no prevén la

${ }^{25}$ Voragine, Jacobus de, The Golden Legend, Vol. II, p. 25. 
situación y deben ir a comprar aceite. Cuando regresan, el esposo ha mandado cerrar las puertas y no pueden ingresar a las bodas. De acuerdo con los exégetas, esta parábola se refiere al Juicio Final y es una incitación a los fieles para mantenerse siempre vigilantes a fin de que la muerte no los sorprenda en pecado y puedan así presentarse limpios y puros ante Dios.

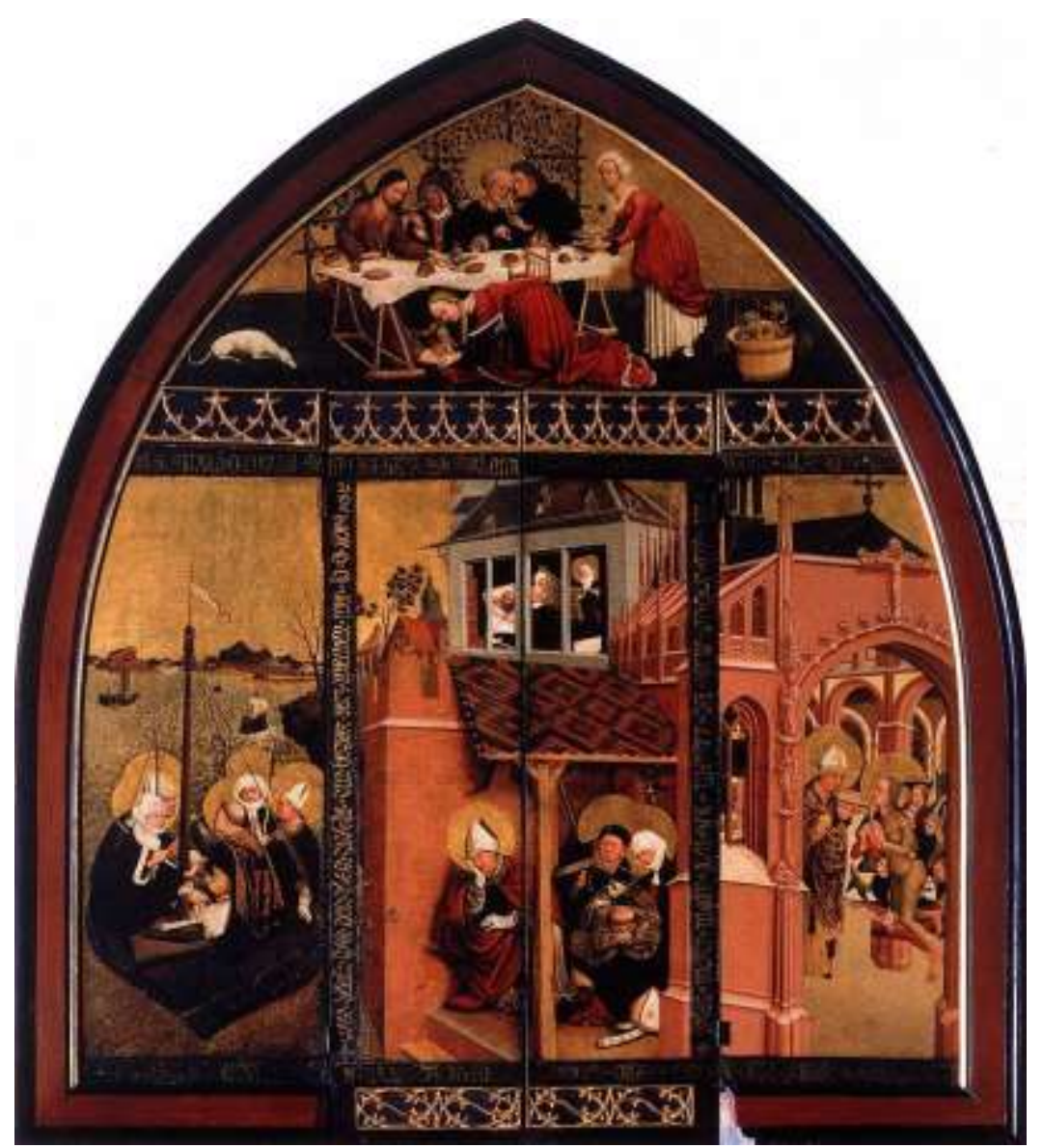

Fig. 9. Lukas Moser, Altar de María Magdalena, 1432, Iglesia de Sta. María Magdalena, Tiefenbronn, Tomado de https://en.wikipedia.org/wiki/Lucas_Moser\#/media/File:Lucas_Moser_Magdalene Altar - WGA16288.jpg

El teatro religioso popularizó el tema y, a partir del siglo XII, las vírgenes prudentes se asocian a la Virgen María, virgen prudente por excelencia, convirtiéndose así en símbolo del Triunfo de la Castidad. ${ }^{26}$ Marta reafirma y enaltece así su condición de virgen. La similitud se enfatiza por las palabras de la santa al referirse a Satanás ya que en obras plásticas alemanas y francesas, las vírgenes necias, vestidas a la moda y con cabellos sueltos y gestos desenfadados, son tentadas por un elegante mozo que oculta bajo su ropa "sapos y gusanos que

\footnotetext{
${ }^{26}$ HALL, James, Dictionary of Subjects \& Symbols in Art, p. 343.
} 
revelan la auténtica naturaleza del seductor". ${ }^{27}$ Este Seductor es Satanás disfrazado, que devora a sus víctimas como los sapos y gusanos a las suyas. ${ }^{28}$

Se cuenta que san Frontón, primer obispo de Périgueux y contemporáneo de Marta, quedó dormido mientras celebraba misa. ${ }^{29}$ El diácono lo despierta para pedirle la bendición, y el santo relata que había sido transportado a Tarascón por Jesucristo para asistir a los funerales de la santa. ${ }^{30}$ Para probarlo, manda emisarios a Tarascón para que rescaten su anillo de oro y sus guantes de plata, confiados al sacristán durante la ceremonia. Traen su anillo, pero un solo guante, pues el par correspondiente había sido retenido por el acólito como recuerdo de la ocasión. Por ello, iconográficamente san Frontón es representado con un guante único.

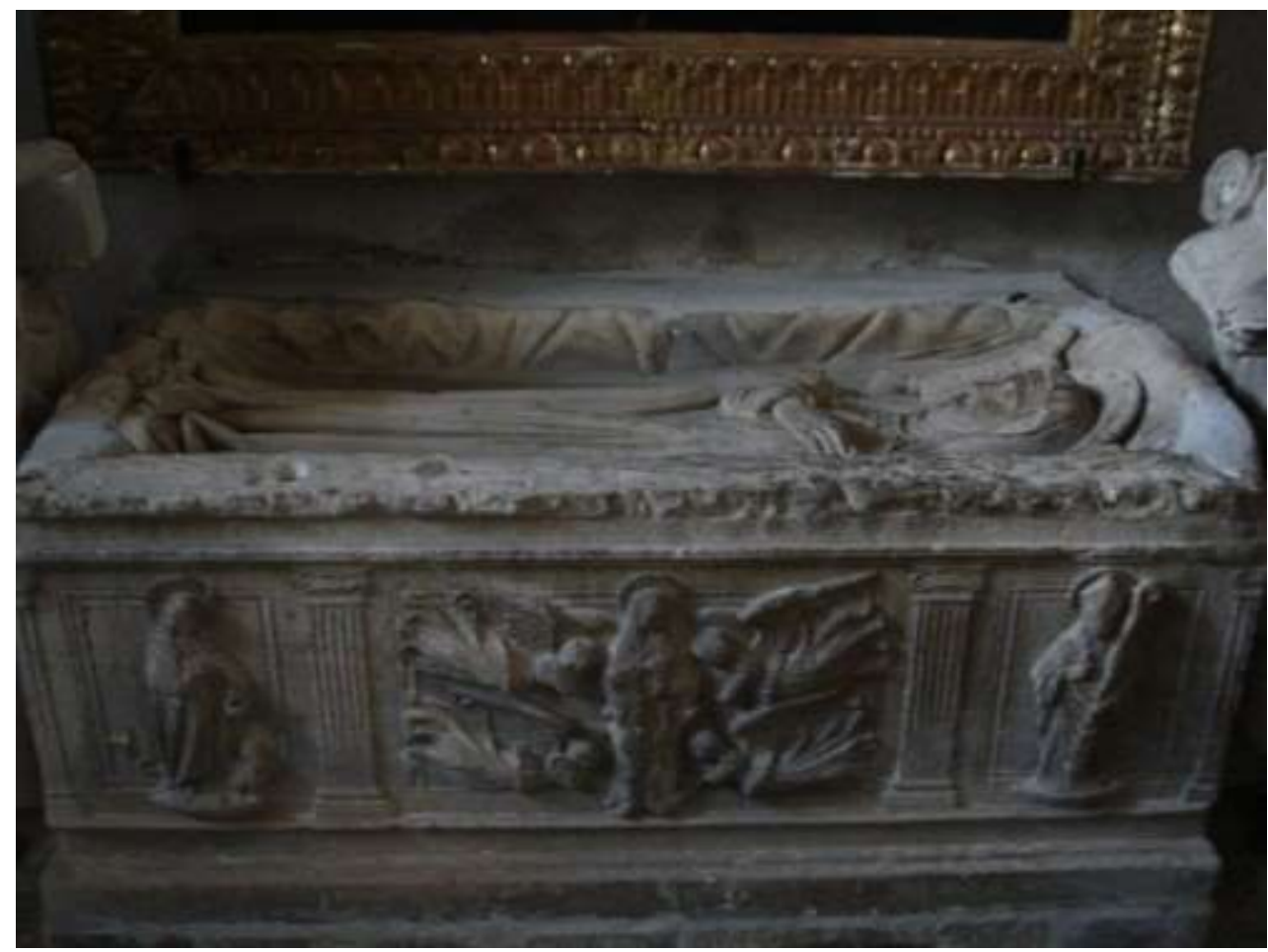

Fig. 10. Sepulcro de Santa Marta, Iglesia de Santa Marta, Tarascon. Tomado de http://www.preguntasantoral.es/2012/12/santas-marta-y-maria-de-betania/

Es tradición que la vida de Marta fue escrita por su servidora Martilla, que murió diez años después que su ama y sus relatos fueron recogidos por las diferentes fuentes que tratan la vida de la santa. A fines del siglo $\mathrm{XII}^{31}$ se

\footnotetext{
${ }^{27}$ RÉAU, Louis, Iconografía del Arte Cristiano, Tomo 1, vol. 2, p. 372.

${ }^{28}$ Para mayor información sobre el tema, ver MANZI, Ofelia, GRAU-DIECKMANN, Patricia, "La reina testigo: Jeanne d'Evreux en su Libro de Horas", Temas Medievales, No 12, pp. 83-95.

${ }^{29}$ Voragine, Jacobus de, The Golden Legend, Vol. II, p. 25.

${ }^{30}$ RÉAU, Louis, Iconografía del Arte Cristiano, Tomo 2, vol. 3, p. 576.

${ }^{31}$ Chauber, V., Schindler, H., Diccionario ilustrado de los santos, p. 478-480.
} 
descubrió en Tarascón un cuerpo que se decía era el de Santa Marta, y el sitio se convirtió en lugar de peregrinación. Se erigió la iglesia de Sainte Marthe, expresamente construida para conservar sus reliquias. En su cripta se encuentra el sarcófago vacío de la santa.

\section{Conclusión}

Se convirtió en patrona de las amas de casa, de las criadas, en especial de las cocineras. Es patrona de la hostelería, de los camareros y de los mozos, de las mucamas, y de todos los servidores domésticos en general.

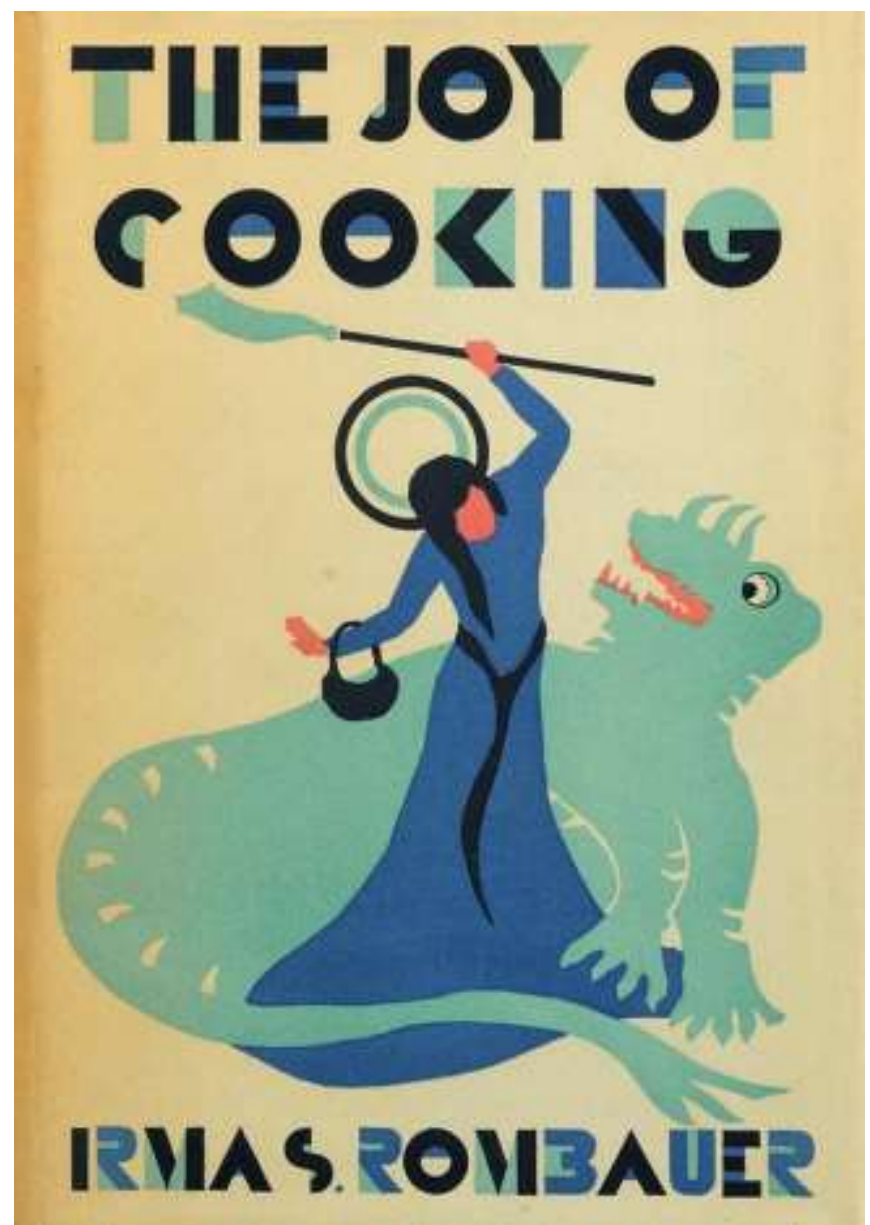

Fig. 11. La Alegría de Cocinar, Libro de cocina con la imagen de Santa Marta ahuyentando al dragón con un lampazo, 1931. Tomado de http://www.letterology.com/2013/12/holiday-cookbookery_5492.html

Protege a los dietólogos, a los dueños de pensiones y hoteles, también a los trabajadores del lavado, a las mujeres legas solteras, a los viajeros, a los escultores, a los pintores, y además se la invoca contra las hemorragias. Finalmente, es la patrona de los moribundos. Iconográficamente se la representa con vestidos sencillos y rasgos de matrona severa e incluso áspera. Sus atributos 
son una escoba, un cucharón o una cuchara, un llavero suspendido de su cintura, un vaso con ungüento. También se la representa con un cubo de agua bendita, que a veces se confunde con un utensilio de limpieza, y con un libro, un rosario y un dragón.

Al contrastar constantemente a Marta con su fascinante y polémica hermana, se le ha convertido en una figura desdibujada y anodina, a pesar de que los exégetas han realzado su importancia como símbolo de la vida activa. Muchos teólogos han analizado la conducta de ambas hermanas, contraponiéndolas, comparándolas, ensalzando alternativamente a una $\mathrm{u}$ a otra en sus virtudes y talantes, pero, sobre todo, intentando decidirse cuál de las dos actitudes (la vida contemplativa de María o la activa de Marta) era superior a la otra. Se ha querido ver en Marta a la Sinagoga con los conversos del judaísmo, y en María a la Iglesia, con sus conversos gentiles. $^{32} \mathrm{O}$ a la Iglesia presente en Marta, y a la Iglesia futura en María. $^{33}$

Abelardo, el de los desgraciados amores que le costaron su virilidad, interpretó el pedido de colaboración de Marta como la exigencia del primer núcleo de seguidores de Cristo de que los nuevos adeptos se convirtieran al judaísmo y se circuncidaran, y vio en la actitud de María a los pies de Cristo el mensaje de que debía prestarse mayor atención a las palabras de Jesús que a la ley mosaica. ${ }^{34}$ Los Padres griegos descubrieron en la admonición de Jesús a Marta ("Marta, Marta...") una cariñosa pero firme llamada de atención sobre la excesiva preocupación por las cosas materiales. $^{35}$

En su intento por conciliar las posiciones de Marta y de María, los exégetas buscaron identificar a las hermanas con otras duplas religiosas: Pedro y Juan, Isabel y la Virgen María, Belén y Jerusalén y, sobre todo, se las identificó con las esposas del patriarca Jacob: Raquel y Lía. Enamorado de la belleza de Raquel (María) Jacob es obligado por su suegro a casarse primero con la primogénita Lía (Marta). La comparación es decididamente poco halagüeña para Marta, ya que las características de Lía son su fealdad y sus ojos legañosos. En definitiva, el trámite obligado de su casamiento fue la condición para que Jacob pudiera acceder a la que verdaderamente amaba.

Las representaciones de Marta en el arte no son frecuentes. Siempre a la sombra de su hermana pecadora - arrepentida, pero siempre provocadora - Santa Marta ocupa un minúsculo lugar entre las variadas representaciones de los santos. Sin pizca de piedad por esta santa patrona de quienes con amor y esmero cuidan los

\footnotetext{
32 OrígenEs, Frag. 72 de la Homilía sobre Lucas. En CONSTABle, Giles, Three Studies in Medieval Religious and Social Thought, p. 15.

${ }^{33}$ En CONSTABLE, op. cit., p. 16.

${ }^{34}$ En CONSTABLE, op. cit., p. 16.

${ }^{35}$ Basilio de Cesarea y Nilo de AnCyra. En Constable, Giles, Three Studies in Medieval Religious and Social Thought, Cambridge University Press, 1995, p. 14.
} 


\section{Patricia GrAU-DiECKMANN, Santa Marta, guardiana de hogares ajenos}

hogares propios o ajenos, la frase cruel de Louis Réau define lapidariamente su destino: "con el cucharón y el dragón, esta santa sin amor sedujo tan poco a los artistas como a Jesús". 36

$$
* * *
$$

\section{Fuentes y Bibliografía}

\section{Fuentes}

Basilio de Cesarea y Nilo de Ancyra. En Constable, Giles, Three Studies in Medieval Religious and Social Thought, Cambridge University Press, Cambridge (UK), 1995, p. 14.

Constable, Giles, Three Studies in Medieval Religious and Social Thought, Cambridge University Press, Cambridge (UK), 1995.

Biblia de Jerusalén, Bilbao, Desclée de Brouwer, 1998.

Eusebio DE CeSAREA, Historia Eclesiástica (Texto bilingüe. Versión española, Introducción y Notas de Argimiro Velasco-Delgado), Biblioteca de Autores Cristianos BAC. En

https://archive.org/stream/EUSEBIOHistoriaEclesistica/EUSEBIO\%20Historia \%20Eclesi\%C3\%A1stica djvu.txt - Consulta 13/5/2017.

Evangelios Apócrifos, Colección: Biblioteca Personal de J. L. Borges, Ed. Hyspamérica, Ediciones Argentinas S.A., Buenos Aires, 1985, Tomo 1.

ORíGENES, Frag. 72 de la Homilía sobre Lucas, ed. Henri Crouzel, François Fournier, y Pierre Péricho (SC87, Paris 1962). En CONSTABLE, 1995.

Voragine, Jacobus de, The Golden Legend, Volúmenes I y II, Princeton University Press, Princeton, 1995.

\section{Bibliografía}

Arqueología, Historia y viajes sobre el mundo Medieval, $\mathrm{N}^{0} 36$, septiembre 2010, Barcelona, España.

GERARD, André-Marie, Diccionario de la Biblia, Anaya y Mario Muchnik, Madrid, 1995.

Gonen, Rivka, Biblical Holy Places, The Jerusalem Publishing House, Jerusalén, 1999.

Graves, Robert, Patai, Raphael, Los Mitos Hebreos (Traducción de Luis Echávarri), Editorial Losada, Buenos Aires, 1969. Primera edición 1963.

HALl, James, Dictionary of Subjects \& Symbols in Art, New York, 1974.

${ }^{36}$ RÉAU, Louis, Iconografía del Arte Cristiano, Tomo 2, Vol. 4, p. 345. 
KonING, Frederik, Diccionario de demonologia, Ed. Bruguera, Barcelona, 1974.

MANZI, Ofelia, GRAU-DIECKMANN, Patricia, "La reina testigo: Jeanne d'Evreux en su Libro de Horas", Temas Medievales, $\mathrm{N}^{\circ}$ 12, Consejo Nacional de Investigaciones Científicas y Técnicas (CONICET), Instituto Multidisciplinario de Historia y Ciencias Humanas, Departamento de Investigaciones Medievales, Buenos Aires, 2004.

RÉAU, Louis, Iconografía del Arte Cristiano, Tomo 1, vol. 2: Iconografía de la Biblia - Nuevo Testamento (Traducción Daniel Alcoba), Ediciones del Serbal, Barcelona, 1996 (primera edición en francés en 1957 en París).

RÉAU, Louis, Iconografía del Arte Cristiano, Tomo 2, Vol. 3, Iconografía de los santos(Traducción Daniel Alcoba), Ediciones del Serbal, Barcelona, 1996 (primera edición en francés en 1957 en París).

Schauber, Vera, Schindler, Hans Michael, Diccionario ilustrado de los santos (Traducción de Luis Miralles de Imperial), Grijalbo / Mondadori, Barcelona, 2001.

The Oxford Dictionary of World Religions, editado por John Bowker, Oxford University Press, Oxford / New York, 1997. 